\title{
Comparative analysis of the feeding ecology of two pelagic forage fishes: capelin Mallotus villosus and walleye pollock Theragra chalcogramma
}

\author{
Matthew T. Wilson*, Christina M. Jump, Janet T. Duffy-Anderson \\ Alaska Fisheries Science Center, National Oceanic and Atmospheric Administration, 7600 Sand Point Way NE, Seattle, \\ Washington 98115, USA
}

\begin{abstract}
Pelagic forage fishes are an important component in the transfer of trophic energy in marine ecosystems. Capelin Mallotus villosus and age-0 walleye pollock Theragra chalcogramma are pelagic forage fishes whose alternate fluctuations in abundance have been associated with systemwide biotic reorganization of the Gulf of Alaska (GOA) ecosystem. To better understand differences between these fishes, we compared their feeding ecology using samples of similar-sized (39 to $126 \mathrm{~mm}$ ) individuals collected together in midwater trawl hauls during September 2000 to 2001 in the western GOA. Zooplankton samples were used to characterize prey availability. The comparative analysis focused on diet, feeding chronology, daily ration, and prey selectivity. The diet of both species mostly consisted of small copepods, large copepods, adult and juvenile euphausiids, thecosome pteropods, and larvaceans; consequently, the overall diet overlap was high. The diet overlap of fish from some samples, however, was low. Capelin fed mostly during crepuscular periods while pollock mostly fed at night. The daily ration estimate for capelin was low (1.8\% body weight [BW]) relative to pollock $(5.2 \%$ BW). Chesson's index of selectivity indicated preferential selection of euphausiids (adult and juvenile) by capelin and age-0 pollock. At euphausiid-poor locations, capelin stomachs were mostly empty while pollock stomachs contained alternate prey. Selectivity of amphipods, large copepods, larvaceans, and reptantians was higher for age-0 pollock than for capelin. Consumption of euphausiids increased with their abundance in the plankton, and consumption:biomass ratios indicate that localized depletion could occur. We hypothesize that capelin increase foraging mobility while age-0 pollock switch to alternate prey as a competitive response to limited euphausiid availability.
\end{abstract}

KEY WORDS: Capelin · Age-0 walleye pollock · Diet overlap · Prey selectivity Resale or republication not permitted without written consent of the publisher

\section{INTRODUCTION}

Predator-prey interactions can reveal mechanisms that are important in structuring animal communities. In marine ecosystems, small fishes are an important intermediate trophic link due to their abundance and availability as prey (Cury et al. 2000, Hunt et al. 2002). Although taxonomically diverse, these fishes are collectively referred to as 'forage fishes' (Springer \& Speckman 1997). In the pelagic realm, most forage fishes are planktivorous and vary in energy density (Iverson et al. 2002, Eder \& Lewis 2005). Consequently, the collective nutritional value of pelagic forage fishes (hereafter referred to as forage fishes) changes with species composition. Anderson \& Piatt (1999) demonstrated that in the Gulf of Alaska (GOA) climaterelated change in forage fish community composition during the 1980's was related to large-scale biotic restructuring. Notable in this restructuring was a decline in capelin abundance and a subsequent increase in walleye pollock abundance. Spatial differences in forage fish community composition have since been demonstrated (Abookire \& Piatt 2005). Due to heterogeneity in the prey field (Folt \& Burns 1999), 
feeding ecology is relevant to fish spatial distribution. Accordingly, in this study, we compare the feeding ecology of 2 pelagic forage-fish species for evidence that might subsequently be related to differences in spatial distribution.

Capelin Mallotus villosus, Osmeridae and juvenile walleye pollock Theragra chalcogramma, Gadidae, often dominate forage fish communities in the North Pacific and Bering Sea. Both are noted as key ecological links in the transfer of energy to larger fishes, birds, and marine mammals (Hatch \& Sanger 1992, Yang \& Nelson 2000, Zeppelin \& Sinclair 2002). Payne et al. (1999) found that capelin were $33 \%$ greater in energy density $\left(\mathrm{kcal} \mathrm{g}^{-1}\right)$ than juvenile walleye pollock, although this varies with capelin reproductive state (Anthony et al. 2000). Too little is known about the feeding ecology of these fishes to judge whether the difference in energy density can be explained by diet.

Capelin are small, short-lived (max. age 5 yr), streamlined schooling fishes common in coastal pelagic habitats (Gjøsæter 1998, Brown 2002, Mecklenburg et al. 2002). They spawn during the spring and summer mostly as age- 2 and age- 3 individuals (ca. $\geq 10 \mathrm{~cm}$ fork length [FL]) (Pahlke 1985). In contrast, walleye pollock are relatively large, long-lived (max. age 22 yr) gadids that congregate semi-pelagically in deep parts of the continental shelf and slope (Mecklenburg et al. 2002, Dorn et al. 2004). They spawn in early spring mostly as age-4 and older individuals (ca. $\geq 40 \mathrm{~cm}$ FL, Dorn et al. 2004). Many pollock spend their first year in coastal pelagic nurseries (Brodeur \& Wilson 1996). By autumn, in the GOA, they are comparable in size to the capelin (ca. $10 \mathrm{~cm}$ ) with which they commonly co-occur. Later, as yearlings, walleye pollock are relatively large, occur in deep water, and their interaction with capelin is characterized more as a potential predator than a potential competitor (Yang et al. 2005). Thus, the temporal and geographic overlap between capelin and walleye pollock during autumn in the GOA represents a near ideal field setting in which to compare their feeding ecology because similar-sized individuals can be collected at the same location (i.e. syntopically), which minimizes fish size and prey-field effects.

In general, capelin and walleye pollock exploit similar prey resources. Calanoid copepods and euphausiids are the major prey (Vesin et al. 1981, Naumenko 1984, Brodeur \& Wilson 1996, Sturdevant 1999, O'Driscoll et al. 2001, Orlova et al. 2002), but larvaceans, amphipods, and other prey are important in relatively euphausiid-poor areas (Gjøsæter 1998, Wilson et al. 2005). Evidently, there is some potential for these fishes to compete for prey. Furthermore, evidence is accumulating that their grazing can substantially depress standing stocks of prey (Vesin et al. 1981,
Gjøsæter 1998, Duffy-Anderson et al. 2002, Ciannelli et al. 2004). Competition might be expected to intensify during autumn due to further reduction in prey availability resulting from a seasonal decline in zooplankton (Coyle \& Pinchuk 2003). Thus, the field study we undertook was designed to rigorously compare the feeding ecology of 2 central and potentially competing pelagic forage fishes in the GOA by minimizing effects of fish size and prey-field in order to resolve possible species-specific and competition effects.

\section{MATERIALS AND METHODS}

Field collections. The study area was situated immediately downstream of Shelikof Strait (Fig. 1), which is where the largest aggregation of GOA pollock spawn in early spring (Dorn et al. 2004). Historically, age-0 pollock and capelin are abundant in this area (Wilson et al. 1996, Wilson 2000). Samples were collected during 2 research cruises of the NOAA Ship 'Miller Freeman' during September 2000 and 2001. Samples used in this study were selected from a larger collection based on the co-occurrence of capelin and age-0 pol-

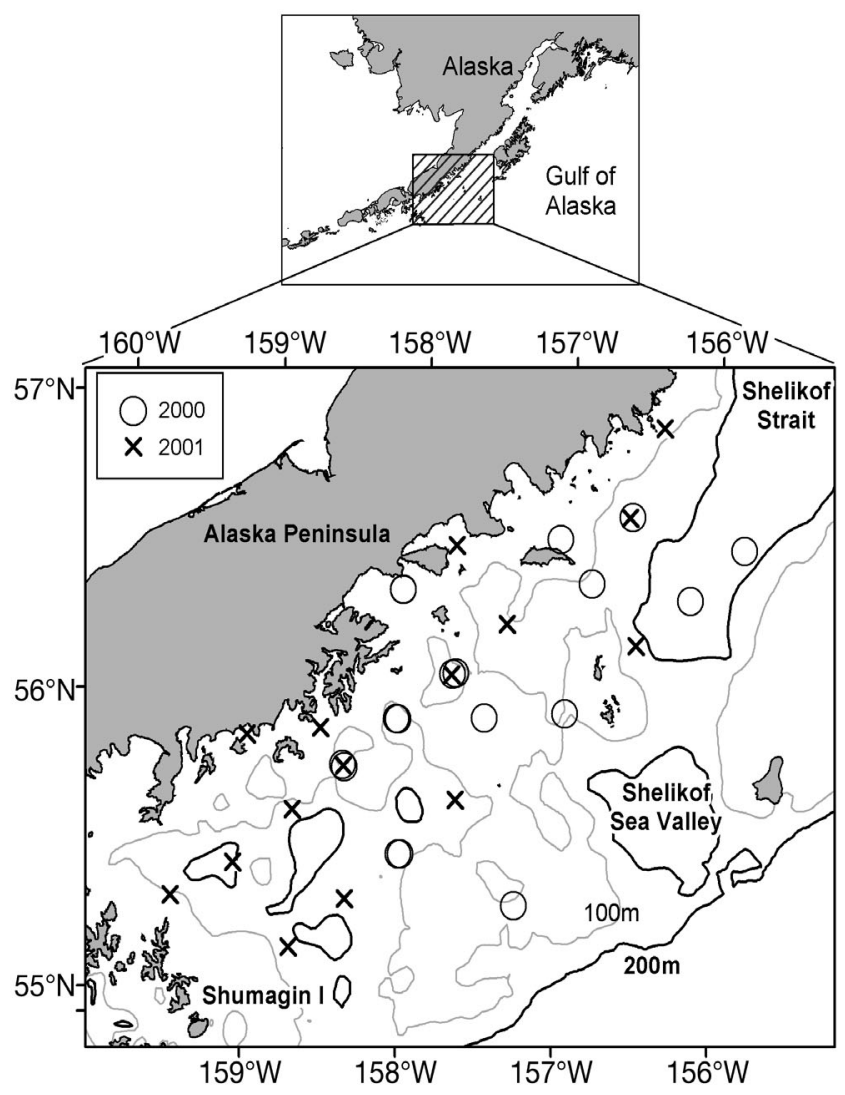

Fig. 1. Station locations where 698 capelin and age-0 pollock were collected during September 2000 to 2001 in the western Gulf of Alaska 
lock in midwater trawl catches, which included day (09:00 h to 20:00 h Alaska Daylight Time [ADT]), night (before 07:00 h or after 22:00 h ADT), and twilight collections. Sunrise and sunset occurred at ca. 08:00 h and 21:00 h ADT.

Fish were collected in 37 trawl hauls (see Table 1). Each sample was collected using a midwater trawl fished with $1.5 \times 2.1 \mathrm{~m}$ steel V-doors (566 kg each) and equipped with a $3 \mathrm{~mm}$ codend liner. The trawl was fished obliquely through the water column at a ship speed of 2.5 to 3.0 knots and a wire retrieval rate of $10 \mathrm{~m} \mathrm{~min}^{-1}$. Fish were frozen $\left(-80^{\circ} \mathrm{C}\right.$ then transferred to $-20^{\circ} \mathrm{C}$ ) within an hour of landing. Relative to preservation in $10 \%$ formalin, freezing did not affect prey count (paired- $t, \mathrm{n}=5, \mathrm{p}=0.656$ ) or prey weight (paired- $t, \mathrm{n}=5, \mathrm{p}=0.518$ ). All capelin were post-larval (>60 mm standard [SL]) individuals, and all walleye pollock were age-0 juveniles $(<113 \mathrm{~mm}$ SL), which were distinctly smaller than older individuals (>119 mm SL) (Brodeur \& Wilson 1996).

Plankton samples were collected at 34 of the fish sampling locations to obtain information on the background prey field and enable calculation of prey selectivity (Table 1). Each plankton sample was collected with a $1 \mathrm{~m}^{2}$ Tucker trawl (0.333 mm mesh nets) fished obliquely from $200 \mathrm{~m}$ to the surface. Towing speed was adjusted to maintain a $45^{\circ}$ wire angle at a wire retrieval rate of $20 \mathrm{~m} \mathrm{~min}^{-1}$. A SBE 19 SeaCat CTD profiler (Sea-Bird), attached in-line between the wire terminus and trawl, was used for real-time monitoring and recording of net depth, water temperature, and salinity. The first net was used to sample that portion of the path below the thermocline or $40 \mathrm{~m}$ depth. The second net was used to sample the shallower portion of the path. All nets were mechanically tripped to open and close. The plankton sample was preserved in a sodium borate-buffered solution of $5 \%$ formalin. Numerical composition of plankton samples was determined in Sczeczin, Poland, by the Plankton Sorting and Identification Center following Alaska Fisheries Science Center protocol. This protocol mandates a much finer resolution of copepod and euphausiid species and life stages than is practically available from the stomach content data. Therefore, estimates of copepod abundance in the plankton were combined into 2 categories: Copepoda $<2 \mathrm{~mm}$ prosome length (PL), and Copepoda $\geq 2 \mathrm{~mm} \mathrm{PL}$, which conformed to the prey-size categories (see 'Laboratory examinations' subsection, below) used to group the diet data. Similarly, euphausiid taxa were combined into 2 categories: Euphausiid adult and juvenile $(\mathrm{a}+\mathrm{j})$, and euphausiid furcilia and calyptopis $(\mathrm{f}+\mathrm{c})$, which are larval forms.

Laboratory examinations. Up to 10 individuals of each species were selected by size from the preserved samples so that the different sizes in each sample were reasonably well represented. Overall, 698 fish were selected from 37 samples. Fish were thawed in seawater. Standard length (SL) and whole wet body weight of each thawed fish was used to estimate species-specific length-weight relationships. Each fish was measured to the nearest $1 \mathrm{~mm} \mathrm{SL}$, blotted dry, and weighed to the nearest $1 \mathrm{mg}$. Lengths and weights were converted to fresh-fish equivalents (Buchheister \& Wilson 2005) assuming that the effect of freezing on capelin SL was equivalent to its effect on FL. Leastsquares linear regression models were fitted to the ln-transformed fresh-fish data.

Diet was determined by analyzing fish stomach contents. Stomachs were excised between the esophagus and pylorus and stored individually in a sodium borate-buffered $10 \%$ formalin solution. None of the stomachs were flaccid so regurgitation was not believed to be a problem.

Stomach contents were dissected from the preserved samples, blotted dry and weighed to the nearest $0.01 \mathrm{mg}$. This weight was used to calculate stomach content weight as percent body weight $(\% \mathrm{BW}=$ stomach content weight/(preserved whole wet body weight - stomach content weight) $\times 100$ ). The contents were then teased apart and sorted into broad taxonomic categories following Brodeur et al. (2000). Each taxonomic category was comprised of subcategories (prey-quality categories) to indicate digestion and fragment size: $1=<50 \%$ intact and well-digested, $2=$ $>50 \%$ intact but well-digested, $3=$ largely intact but digested, $4=$ intact and fresh. Most prey showed signs of digestion (i.e. prey-quality categories 1 to 3 ) so net feeding was probably negligible. Taxonomic composition was quantified by prey count, prey weight, and frequency of occurrence. Weight was measured to the nearest $0.01 \mathrm{mg}$.

Diet analysis. To ensure that conclusions regarding comparative feeding ecology were independent of the coarse taxonomic categorization of stomach contents, finer taxonomic composition and individual weight of prey was examined using subsets of the diet data. Subsamples of mostly intact (prey-quality categories 3 and 4) copepods ( $<2 \mathrm{~mm}$ and $\geq 2 \mathrm{~mm}$ PL) and euphausiids (adults and juveniles) were identified to the lowest possible taxonomic level (Szabo \& Gardner 1982, Kathman et al. 1986) and compared between predator species. Individual weight was calculated for prey groups represented by prey items of quality category 3 and 4 . Individual prey weight was first calculated for each fish (prey weight divided by prey number) and then averaged by sample and predator. Pairwise $t$-tests were used to detect differences in mean individual prey weight between predators. Prey groups represented in fewer than 5 samples were excluded from the comparisons. 
Diet overlap between capelin and age-0 walleye pollock was quantified using Horn's index of resource overlap (Horn 1966). This index was chosen because it (1) performs well in comparison to other overlap indices (Cailliet \& Barry 1979), (2) has low bias due to variation in sample size and resource categories (Smith \& Zaret 1982), and (3) was previously used to study age-0 pollock diet in the northeast Pacific (Sturdevant et al. 2001). Horn's index, $R_{0}$, was calculated as

$$
R_{0}=\frac{\sum_{i=1}^{m}\left(p_{1 i}+p_{2 i}\right) \ln \left(p_{1 i}+p_{2 i}\right)-\sum_{i=1}^{m} p_{1 i} \ln \left(p_{1 i}\right)-\sum_{i=1}^{m} p_{2 i} \ln \left(p_{2 i}\right)}{2 \ln (2)}
$$

where $p_{1 i}$ and $p_{2 i}$ are the percentages of the $i^{\text {th }}$ group of $m$ prey taxa in the stomach contents of predator 1 and 2 , respectively. The value of $R_{0}$ ranges from -1 (no overlap) to 1 (perfect overlap). Following Sturdevant et al. (2001), diets were considered similar for $R_{0}>0.6$. Overlap was first calculated using prey weight and then using prey count. In either case, the Miscellaneous (rare items of uncertain identification) and Unidentified (unidentifiable digested material) prey categories were excluded. Diet overlap between capelin and age-0 pollock was calculated by year, and then for each of the 37 samples.

Nonlinear regression and Spearman's rank correlation were used to examine diel collection time and mean fish size effects on among-sample variability in diet overlap. A nonlinear least-squares procedure was used to evaluate the model,

$$
R_{0}=a+b_{1}\left\{\sin \left[2 \pi / 24\left(t-b_{2}\right)\right]\right\}
$$

for evidence of a significant association between diet overlap $\left(R_{0}\right)$ and collection time ( $t$, decimal $\mathrm{h}$ ) using SAS for Windows (release 8.02). The model was fitted using the Newton method of iteration and an assumed, fixed, periodicity $(2 \pi / 24)$, based on apparent pattern, to reduce the number of parameters to be estimated: $a$ (vertical shift), $b_{1}$ (amplitude), and $b_{2}$ (time shift). Spearman's rank correlation was used to determine the significance of the relationship between diet overlap and mean length of each predator species, and the difference in mean predator length. Finally, correlation analysis was used to elucidate what dietary components were most responsible for the variation in diet overlap among samples.

The implications of different predator feeding chronologies were explored using daily trajectories of stomach content weight to estimate feeding parameters (periodicity and rates of ingestion, egestion, and ration) (Sainsbury 1986). Stomach fullness, as indicated by median \% BW, was input to MAXIMS models as implemented using SAS following Richter et al. (1999) to provide parameter and parameter variance estimates. The model assumes constant ingestion during the feeding period, and an exponential rate of evacuation:

$$
\mathrm{d} S / \mathrm{d} t=J-E S
$$

where $S$ is stomach content weight (\% BW), $J$ is the rate of ingestion $\left(\% \mathrm{BW} \mathrm{h}^{-1}\right)$, and $E$ is the instantaneous rate of evacuation $\left(\mathrm{h}^{-1}\right)$. The model can be applied to feeding chronologies that include 1 or 2 feeding periods per $24 \mathrm{~h}$. Brodeur et al. (2000) applied the same model to age-0 walleye pollock in the Bering Sea, but our parameter estimates for capelin in the Pacific are new. Following Brodeur et al. (2000), the \% BW data were grouped into $3 \mathrm{~h}$ time bins as a somewhat arbitrary compromise between maximizing both the number of samples in each time bin and the number of time bins. Sample sizes were not sufficient to construct separate time series for each year; therefore, the resulting feeding chronologies integrate potential interannual effects.

Prey selectivity. Prey selectivity was quantified using Chesson's index of selectivity, $\alpha_{i}$ (Chesson 1978). This index is useful for among-sample comparisons because it incorporates the relative abundance of each prey type, but is unaffected by total prey abundance (Lechowicz 1982). Chesson's index was calculated as

$$
\alpha_{i}=\frac{d_{i} / e_{i}}{\sum_{i=1}^{m}\left(d_{i} / e_{i}\right)}
$$

where $d_{i}$ and $e_{i}$ are the percent abundance of prey taxa group $i$ in fish stomachs and in plankton samples, respectively, and $m$ is the number of prey types (e.g. taxonomic groups). The value of $\alpha_{i}$ ranges from 0 to 1 with a critical value of $1 / m$, values $<1 / \mathrm{m}$ indicate negative selectivity (i.e. avoidance) and values $>1 / \mathrm{m}$ indicate positive selection (i.e. preference). Plankton catches were expressed as individuals $\mathrm{m}^{-2}$, which was calculated using the volume filtered and the depth range fished with each net, followed by the summing of the standardized catches from both nets. Volume filtered was measured using a calibrated flow meter (General Oceanics) suspended in the center of each net mouth. Prey selectivities for capelin and age-0 walleye pollock were calculated for all samples pooled by year, and for each of the 34 samples. Prey groups not represented in the plankton samples were omitted. Statistical comparisons were made using Wilcoxon paired- $t$ tests for each prey group. Bonferroni corrections were applied to maintain a $\mathrm{p}=0.05$ significance level. 


\section{RESULTS}

There was considerable overlap in the size of fish examined in this study but on average the capelin were $10 \mathrm{~mm}$ longer than the age- 0 walleye pollock (Table 1). The length (L) - weight (W) relationships reflect the relatively streamlined morphology of capelin $\left[\mathrm{W}=\left(2.138 \times 10^{-7}\right) \mathrm{L}^{3.769}, \mathrm{R}^{2}=0.97, \mathrm{n}=330\right]$ as compared to age- 0 walleye pollock $[\mathrm{W}=(3.686 \times$ $\left.\left.10^{-6}\right) \mathrm{L}^{3.195}, \mathrm{R}^{2}=0.97, \mathrm{n}=368\right]$. The average water temperature $(50 \mathrm{~m}$ depth) at the sampled locations was $8.3^{\circ} \mathrm{C}$ and $9.8^{\circ} \mathrm{C}$ in 2000 and 2001 , respectively.

\section{Diet analysis}

Horn's index of dietary overlap was high in $2000\left(\mathrm{R}_{0}\right.$ $\geq 0.95)$ and in $2001\left(R_{0} \geq 0.89\right)$ indicating very similar composition in the diets of capelin and age- 0 walleye pollock. The 5 most frequently encountered, identifiable prey groups were similar for both predator species: copepods $<2 \mathrm{~mm} \mathrm{PL}$, copepods $\geq 2 \mathrm{~mm}$ PL, euphausiid adults and juveniles, thecosome pteropods, and larvaceans (Table 2). Despite the high overlap index, many prey groups were more prevalent among age-0 walleye pollock than among capelin. Cumaceans, mysids, and larval crabs (Reptantia, mostly megalopae) occurred exclusively among age-0 walleye pollock, and the proportional abundance of larvaceans was especially high in pollock stomachs collected during 2001. Of the fishes consumed (Osteichthys), some were identified as larval capelin and the remains of most others appeared smelt-like.

No differences were apparent between pollock and capelin with regard to copepod and euphausiid species consumed. The most common copepods were

Table 1. Midwater and Tucker trawl samples of $\left(\mathrm{N}_{\mathrm{f}}\right)$ fish and $\left(\mathrm{N}_{\mathrm{p}}\right)$ plankton, respectively, used to compare the feeding ecology of age-0 walleye pollock Mallotus villosus and capelin Theragra chalcogramma in the western Gulf of Alaska during September 2000 and 2001. No. of fish comprising midwater trawl samples, averages of maximum trawl depth, temperature $\left({ }^{\circ} \mathrm{C}\right)$ and salinity (psu) at $50 \mathrm{~m}$ water depth, and standard length (SL) are included

\begin{tabular}{|c|c|c|c|c|c|c|c|c|c|c|c|}
\hline \multirow[t]{4}{*}{ Year } & \multirow{4}{*}{$\mathrm{N}_{\mathrm{f}}$} & \multirow{4}{*}{$\begin{array}{l}\text { Max. depth } \\
\text { per haul } \\
\text { (m) }\end{array}$} & \multirow{3}{*}{\multicolumn{2}{|c|}{$\begin{array}{l}\text { Midwa } \\
50 \mathrm{~m} \text { depth } \\
{ }^{\circ} \mathrm{C} \quad \text { psu }\end{array}$}} & wl hc & S (fish Sc & mples) & & \multirow{3}{*}{\multicolumn{2}{|c|}{$\begin{array}{l}\text { Capelin } \\
-\mathrm{SL}(\mathrm{mm})-\end{array}$}} & \multirow{4}{*}{$\begin{array}{c}\text { Tucker } \\
\text { trawl } \\
\text { hauls } \\
\mathrm{N}_{\mathrm{p}}\end{array}$} \\
\hline & & & & & & $\mathrm{e}-0$ pol & ock & \multirow{3}{*}{$\begin{array}{l}\text { No. } \\
\text { fish }\end{array}$} & & & \\
\hline & & & & & No. & $-\mathrm{SL}$ & $\mathrm{mm})$ & & & & \\
\hline & & & & & fish & Mean & Range & & Mean & Range & \\
\hline 2000 & 19 & $20-237$ & 8.3 & 31.8 & 194 & 72 & $39-100$ & 155 & 83 & $63-118$ & 16 \\
\hline 2001 & 18 & $66-183$ & 9.8 & 31.5 & 174 & 74 & $52-100$ & 175 & 85 & $66-126$ & 18 \\
\hline
\end{tabular}

Table 2. Mallotus villosus and Theragra chalcogramma. Taxonomic composition of stomach contents of age-0 walleye pollock and capelin by percent frequency of occurrence (FO), percent of total prey number (No.), and percent of total prey weight (Wt). 'All groups combined': number of non-empty stomachs and total number and total weight $(\mathrm{g})$ of all prey items in the respective 'FO', 'No.', and 'Wt' columns (see Table 1 for sample sizes and number of fish). PL: prosome length; $(a+j)$ : adult + juvenile; $(\mathrm{f}+\mathrm{c})$ : furcilia + calyptopis; na: not applicable

\begin{tabular}{|c|c|c|c|c|c|c|c|c|c|c|c|c|}
\hline \multirow[t]{3}{*}{ Taxonomic group } & \multicolumn{6}{|c|}{ - September 2000} & \multicolumn{6}{|c|}{ — September 2001} \\
\hline & \multicolumn{3}{|c|}{ Age-0 pollock } & \multicolumn{3}{|c|}{ Capelin - } & \multicolumn{3}{|c|}{ Age-0 pollock } & \multirow{2}{*}{$\mathrm{FO}$} & \multicolumn{2}{|c|}{ Capelin } \\
\hline & $\mathrm{FO}$ & No. & $\mathrm{Wt}$ & $\mathrm{FO}$ & No. & $\mathrm{Wt}$ & $\mathrm{FO}$ & No. & Wt & & No. & $\mathrm{Wt}$ \\
\hline Amphipoda & 7 & 0.31 & 0.64 & 1 & 0.02 & 0.03 & 18 & 0.71 & 0.99 & 3 & 0.19 & 0.09 \\
\hline Chaetognatha & 7 & 0.44 & 2.04 & 4 & 0.22 & 0.25 & 11 & 0.35 & 0.80 & 2 & 0.08 & 0.02 \\
\hline Cirripedia & 3 & 0.11 & 0.00 & 0 & 0.00 & 0.00 & 1 & 0.02 & 0.00 & 1 & 0.05 & 0.00 \\
\hline Copepoda,$<2 \mathrm{~mm}$ PL & 63 & 78.31 & 6.93 & 44 & 71.74 & 4.83 & 51 & 25.52 & 1.52 & 20 & 48.50 & 2.26 \\
\hline Copepoda, $\geq 2 \mathrm{~mm}$ PL & 26 & 4.97 & 3.22 & 17 & 2.13 & 1.55 & 45 & 9.27 & 3.99 & 14 & 10.82 & 2.60 \\
\hline Cumacea & 1 & 0.02 & 0.01 & 0 & 0.00 & 0.00 & 1 & 0.01 & 0.00 & 0 & 0.00 & 0.00 \\
\hline Euphausiid $(a+j)$ & 42 & 4.38 & 61.80 & 35 & 4.92 & 66.32 & 69 & 6.95 & 78.08 & 49 & 15.61 & 89.90 \\
\hline Euphausiid $(\mathrm{f}+\mathrm{c}$ ) & 7 & 0.64 & 3.02 & 6 & 7.99 & 10.94 & 10 & 0.34 & 0.14 & 2 & 0.29 & 0.03 \\
\hline Osteichthys & 3 & 0.13 & 13.85 & 3 & 0.36 & 10.13 & 2 & 0.06 & 5.96 & 0 & 0.00 & 0.00 \\
\hline Larvacea & 14 & 1.88 & 0.24 & 7 & 1.36 & 0.08 & 47 & 44.01 & 2.59 & 9 & 12.62 & 0.37 \\
\hline Mysidacea & 0 & 0.00 & 0.00 & 0 & 0.00 & 0.00 & 1 & 0.01 & 0.03 & 0 & 0.00 & 0.00 \\
\hline Reptantia & 15 & 0.78 & 2.19 & 0 & 0.00 & 0.00 & 5 & 0.20 & 0.67 & 0 & 0.00 & 0.00 \\
\hline Thecosomata & 16 & 7.48 & 0.48 & 21 & 10.37 & 0.56 & 25 & 12.23 & 2.20 & 18 & 11.33 & 1.15 \\
\hline Miscellaneous & 4 & 0.17 & 0.06 & 6 & 0.75 & 0.00 & 1 & 0.01 & 0.11 & 0 & 0.00 & 0.00 \\
\hline Unidentified/digested & 44 & na & 5.52 & 51 & na & 5.31 & 58 & na & 2.91 & 47 & na & 3.56 \\
\hline All groups combined & 186 & 6377 & 7.92 & 138 & 4129 & 3.76 & 174 & 8342 & 7.85 & 138 & 3779 & 6.57 \\
\hline
\end{tabular}


Calanus marshallae and Metridia spp., and the most common euphausiid species was Thysanoessa inermis (Table 3 ). The other prey groups consumed were too digested to enable identification within a practical amount of examination time.

Mean individual weight of prey items did not differ between predator species (Table 4). Data were sufficient to test 4 prey groups. Mean weight ranged from $0.083 \mathrm{mg}$ ind ${ }^{-1}$ for thecosome pteropods to $29.789 \mathrm{mg}$ ind.$^{-1}$ for adult and juvenile euphausiids. Given the similarity in specific composition of the major prey items and the mean weights of prey items, it is unlikely that our subsequent use of coarser prey taxonomy greatly affected our conclusions regarding diet comparability.

Table 3. Mallotus villosus and Theragra chalcogramma. Specific taxonomic composition of adult and juvenile euphausiids, and copepods of all sizes $(<2 \mathrm{~mm}$ and $\geq 2 \mathrm{~mm}$ prosome length) that were found in the stomachs of capelin and age-0 walleye pollock collected in the western Gulf of Alaska, September 2000 to 2001. $(\mathrm{a}+\mathrm{j})$ : adult + juvenile

\begin{tabular}{|c|c|c|}
\hline \multirow[t]{2}{*}{ Prey } & \multicolumn{2}{|c|}{ Proportion \% (by number) } \\
\hline & walleye pollock & Capelin \\
\hline \multicolumn{3}{|l|}{ Euphausiids $(a+j)$} \\
\hline Euphausia pacifica & 0.9 & 0.3 \\
\hline Thysanoessa inermis & 31.3 & 24.1 \\
\hline Thysanoessa raschii & 0.6 & 1.6 \\
\hline Thysanoessa spinifera & 17.7 & 9.3 \\
\hline Thysanoessa spp. & 49.6 & 64.6 \\
\hline No. ind. identified & 368 & 330 \\
\hline \multicolumn{3}{|l|}{ Copepods, all sizes } \\
\hline Acartia longiremis & 0.6 & 0.0 \\
\hline Calanus marshallae & 38.9 & 33.5 \\
\hline Calanus spp. & 0.6 & 2.2 \\
\hline Centropages abdominalis & 15.3 & 14.7 \\
\hline Epilabidocera longipedata & 2.5 & 0.0 \\
\hline Eucalanus spp. & 3.2 & 8.5 \\
\hline Metridia okhotensis & 0.0 & 1.8 \\
\hline Metridia spp. & 32.5 & 32.1 \\
\hline Pseudocalanus spp. & 6.4 & 7.1 \\
\hline No. ind. identified & 157 & 224 \\
\hline
\end{tabular}

Table 4. Mallotus villosus and Theragra chalcogramma. Paired- $t$ test results of difference in mean individual weight of intact prey in the stomachs of capelin and age- 0 walleye pollock collected in $\mathrm{n}$ pairs of trawl samples. PL: prosome length; $(a+j)$ : adult + juvenile

\begin{tabular}{|c|c|c|c|c|c|c|}
\hline \multirow[t]{2}{*}{ Prey } & \multirow[t]{2}{*}{$\begin{array}{l}\text { No. } \\
\text { pairs }\end{array}$} & \multicolumn{2}{|c|}{$\begin{array}{l}\text { Mean ind. } \\
\text { prey wt (mg) }\end{array}$} & \multirow[t]{2}{*}{$\begin{array}{c}\text { Mean } \\
\text { difference }\end{array}$} & \multirow[t]{2}{*}{$t$} & \multirow[t]{2}{*}{$\mathrm{p}$} \\
\hline & & Capelin & Pollock & & & \\
\hline Copepods, $<2 \mathrm{~mm} \mathrm{PL}$ & 12 & 0.129 & 0.152 & 0.023 & 1.008 & 0.335 \\
\hline Copepods, $\geq 2 \mathrm{~mm} \mathrm{PL}$ & 9 & 0.551 & 1.289 & 0.738 & 1.455 & 0.184 \\
\hline Euphausiids $(a+j)$ & 13 & 21.312 & 29.789 & 8.477 & 0.912 & 0.380 \\
\hline Thecosomata & 6 & 0.138 & 0.083 & -0.055 & -0.639 & 0.551 \\
\hline
\end{tabular}

Capelin and age- 0 walleye pollock generally exhibited similar size-related diet composition patterns (Fig. 2). The numerical importance of small copepods decreased with fish length while the gravimetric importance of euphausiids increased. The abundance of larvaceans increased with predator size among the age-0 walleye pollock despite indications from larvacean remains recovered from the stomachs that these were relatively small prey items. Closer examination of the data indicates that this unexpected trend largely reflects spatial coincidence during 2001 of high larvacean abundance and large-size age- 0 pollock in the northeastern part of the study area.

Diel variability in diet composition at $3 \mathrm{~h}$ intervals was also generally similar between predators (Fig. 3). In terms of count, euphausiids were relatively abundant in fish collected after midnight and before noon; this was especially evident among capelin. The percentage of stomach content weight due to small prey items (larvaceans, small copepods, and thecosome pteropods) was highest in samples collected near sunset. These general patterns in diet composition were useful in guiding our more rigorous comparison of capelin and age-0 walleye pollock feeding, which utilized fish samples paired by trawl haul to minimize interannual and geographic variation in the prey field.

The analysis of sample-to-sample variation in Horn's index indicated that diet overlap varied from 0 to 0.99 . Only 8 samples had low weight-based overlap. This was associated with low weights of euphausiids (adult and juvenile) in stomach contents ( $p<0.001)$, but it was not associated with collection time $(F=0.03$, $p=0.975$ ) or predator length (Spearman correlation, $\mathrm{p}>0.05$ ). Consequently, weight-based overlap was dropped from further analysis. Diet overlap based on numerical composition was associated with collection time $(F=5.40, \mathrm{p}=0.009)$. It increased throughout the day, peaked just after sunset, and decreased at night with all low $(<0.6)$ values occurring between midnight and 17:00 h ADT (Fig. 4). Within this time frame, overlap was not correlated with predator length $(p>0.25)$.

It was, however, associated with low abundance of small-size prey items (copepods, larvaceans, and thecosome pteropods) in capelin stomachs (Spearman's rho $\geq 0.41, \mathrm{p}<0.043$ ) and a high frequency of empty capelin stomachs (Spearman's rho $=-0.55, \mathrm{p}=0.006)$. Thus, diel variation in overlap was associated with capelin stomach fullness suggesting differences in feeding chronology.

Diel trajectories of stomach fullness suggest that capelin feeding intensified during twilight in contrast to a more 


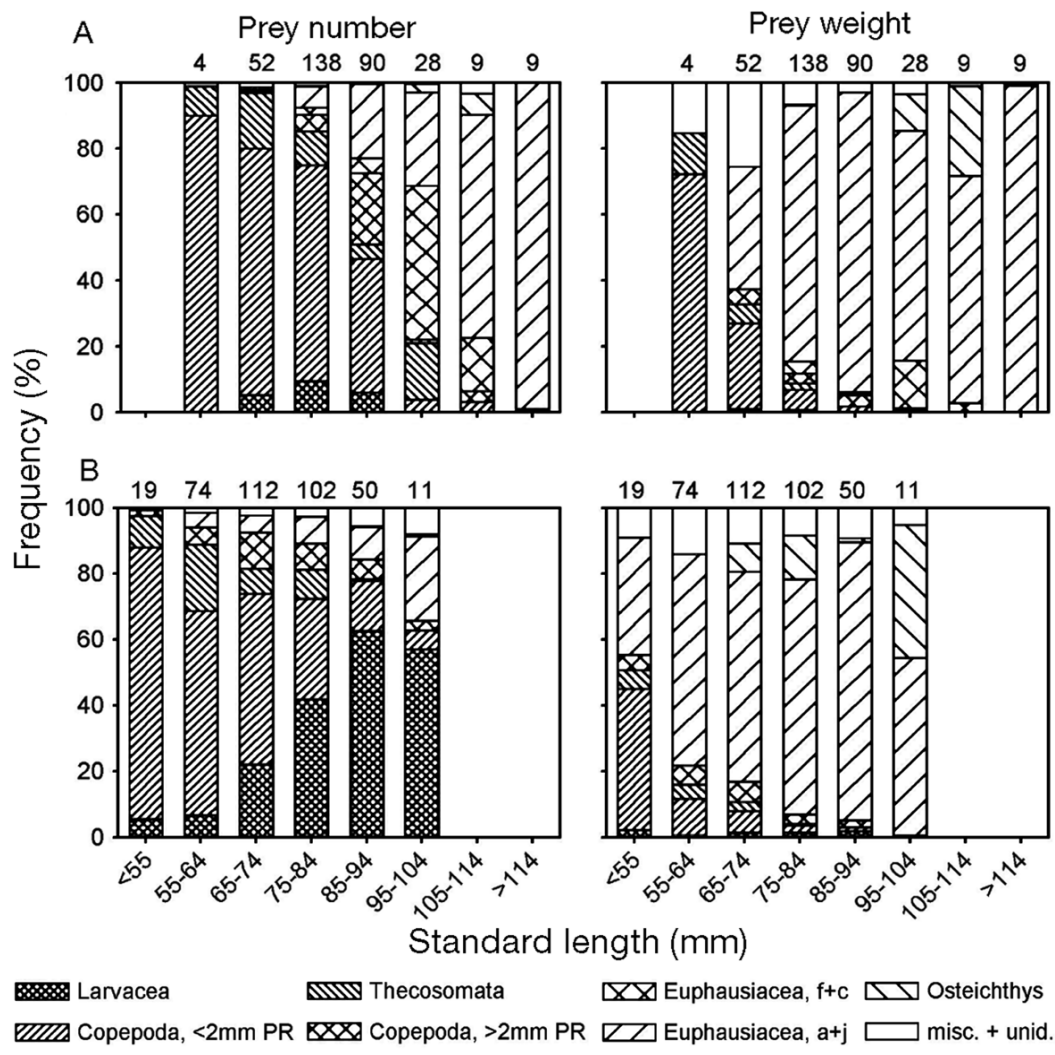

Fig. 2. Mallotus villosus and Theragra chalcogramma. Diet composition by predator length for (A) capelin and (B) age-0 walleye pollock collected during September 2000 and 2001 in the western Gulf of Alaska. Numbers above vertical bars: number of fish stomachs examined

nighttime-based pattern of feeding by age-0 pollock, although variation in stomach fullness was considerable (Fig. 5). Overall, median stomach fullness for capelin was $0.21 \%$ BW $(n=330)$ and median absolute weight of stomach contents was $6.27 \mathrm{mg}$. Capelin stomach fullness peaked during the $3 \mathrm{~h}$ period after sunrise (09:00 to $12: 00 \mathrm{~h}, 0.46 \% \mathrm{BW})$ and again after sunset (21:00 to $24: 00 \mathrm{~h}, 0.43 \% \mathrm{BW})$. The effect of collection time was highly significant (Kruskal-Wallis test statistic $=20.87, \mathrm{p}=0.004)$; however, after applying a Bonferroni correction for multiple comparisons, the only significant pairwise difference was between the time periods $15: 00$ to $18: 00 \mathrm{~h}$ and $21: 00$ to $24: 00 \mathrm{~h}$ (Mann-Whitney U = 720, p < 0.001). For age-0 pollock, overall median stomach fullness was $0.69 \%$ BW (n = 368) and median absolute weight of stomach contents was $19.80 \mathrm{mg}$. Median values increased after sunset and remained at about $1.0 \%$ BW throughout the night. Fullness decreased during the day to a low of $0.21 \%$ BW just prior to sunset. Similar to capelin, collection time was highly associated with stomach fullness (Kruskal-Wallis test statistic $=20.67, \mathrm{p}=0.004)$; however, no pairwise comparisons were significant after applying a Bonferroni correction. Based on these pat- terns, the MAXIMS model was fit to the capelin stomach fullness data assuming 2 feeding periods, and to the pollock fullness data assuming one feeding period in a $24 \mathrm{~h}$ period.

Feeding parameter estimates fit to diel trajectories of median \% BW were bounded by large SEs (Table 5). For capelin, the $95 \%$ CI of the ingestion ( \pm $0.614)$ and evacuation $( \pm 1.465)$ parameters and the estimate of daily ration $( \pm 8.020)$ included zero. Furthermore, the model did not account for a significant amount of the variation in median stomach fullness $(F=8.57, \mathrm{p}=0.108)$. Thus, the capelin feeding parameters must be considered a first approximation. The model fit to the age- 0 walleye pollock data was significant ( $F=41.99$, $\mathrm{p}=0.002$ ) but again the CI for ingestion $( \pm 0.336)$ and evacuation $( \pm 0.404)$ parameters and the estimate of daily ration $( \pm 6.525)$ included zero.

\section{Prey selectivity}

Overall, 6 of the 16 prey groups were preferentially selected by capelin and age-0 walleye pollock (Table 6). Adult and juvenile euphausiids were preferentially selected by both predator species consistently during each year. Associated selectivities $\left(\alpha_{\mathrm{i}}\right)$ for this prey group ranged from 0.208 to 0.619 , well above the critical value $(1 / m=0.063$, see 'Materials and methods'). Mean $( \pm 95 \% \mathrm{CI})$ abundance of adult and juvenile euphausiids in the plankton was estimated to be $135 \pm 92$ ind. $\mathrm{m}^{-2}$ during 2000 and $647 \pm 655$ ind. $\mathrm{m}^{-2}$ in 2001. Other prey groups (larvaceans, Osteichthys, large copepods, euphausiid calyptopis and furcilae, and thecosome pteropods) were also subject to positive selectivity, but the trends were not as strong or consistent as for large euphausiids. The remaining taxonomic groups were proportionally underrepresented in stomachs relative to the plankton samples, except for Cumacea, which are epibenthic and not identified in the plankton samples.

Preferential selection for adult and juvenile euphausiids was further supported by evidence of capelin and pollock switching from other prey to euphausiids as the abundance of euphausiid increased in the water column. Using the 18 samples collected at night, to account for a possible diurnal decrease in euphausiid net catch efficiency, we observed an increase in the mean number of euphausiids in capelin (ANCOVA, $F=25.89$, 


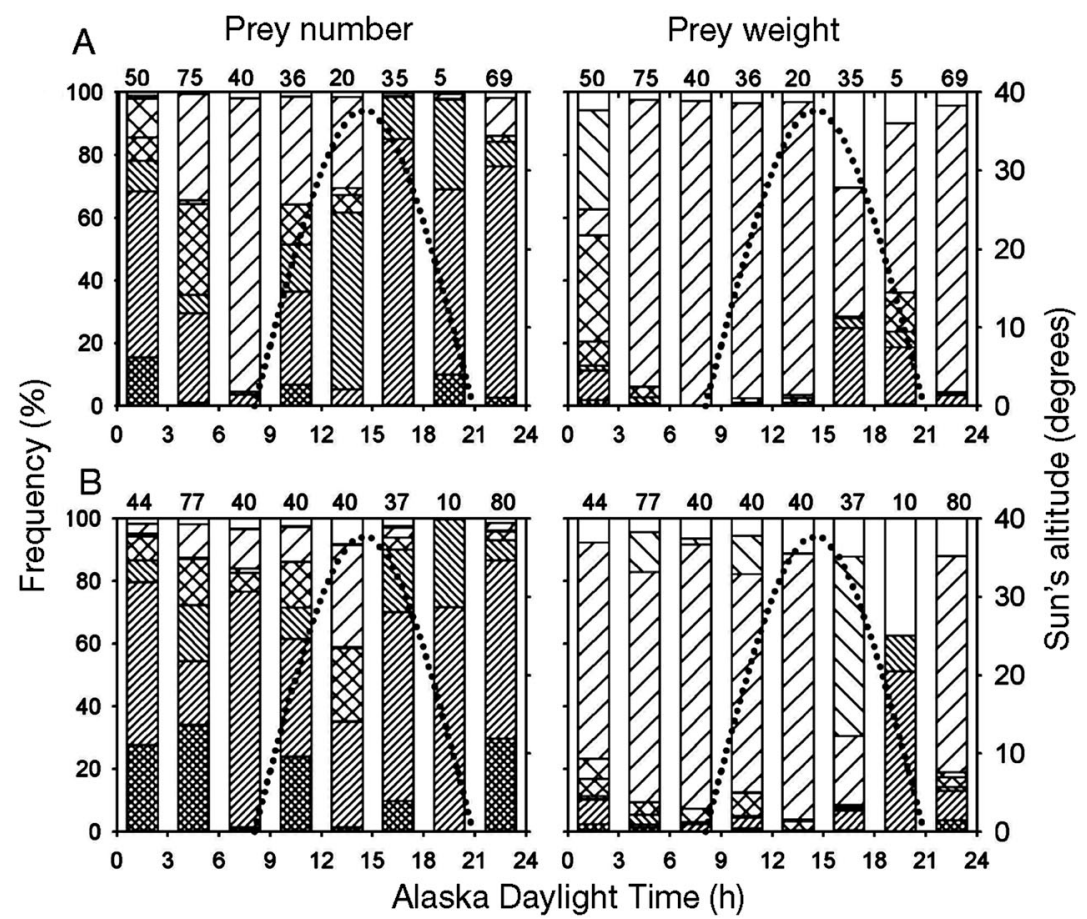

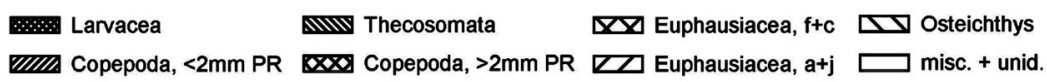

Fig. 3. Mallotus villosus and Theragra chalcogramma. Diet composition by $3 \mathrm{~h}$ time bins (Alaska Daylight Time) for (A) capelin and (B) age-0 walleye pollock collected during September 2000 and 2001 in the western Gulf of Alaska. Numbers above vertical bars: number of fish stomachs examined. Dotted line: hourly predictions of sun altitude at $158^{\circ} 24^{\prime} \mathrm{W}, 56^{\circ} 18^{\prime} \mathrm{N}$ during 11 September (http://aa.usno.navy.mil/)

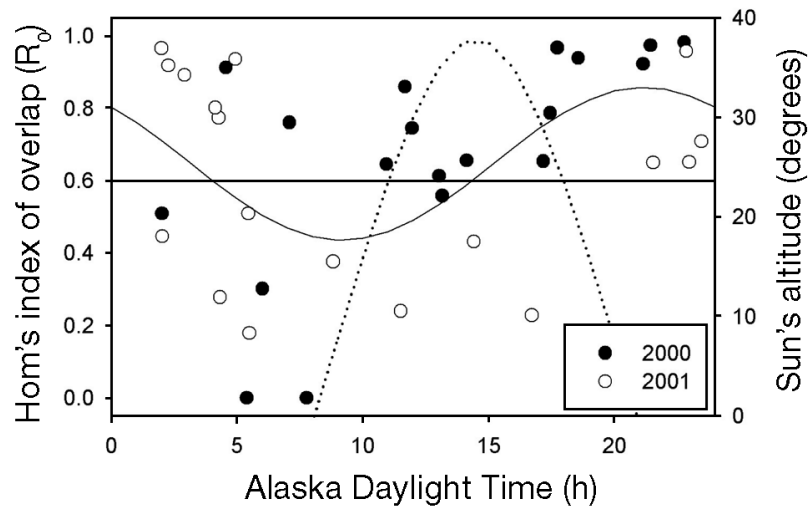

Fig. 4. Mallotus villosus and Theragra chalcogramma. Horn's index of overlap in diet between capelin and age-0 walleye pollock versus Alaska Daylight Time (ADT). Diet composition was based on prey counts. Horizontal line $\left(\mathrm{R}_{0}=0.6\right)$ delineates low and high overlap values. Curved line: curvilinear relationship between diet overlap and ADT $\left(\mathrm{R}_{0}=0.646-\right.$ $0.211\{\sin [0.262 \times(t+3.177)]\} ; \mathrm{n}=37)$ Dotted line: hourly predictions of sun altitude (see Fig. 3 for coordinates and data source) $\mathrm{p}<0.001$ ) and pollock (ANCOVA, $F=$ $31.48, \mathrm{p}<0.001)$ stomachs as the abundance of euphausiids in the plankton increased among sample sites (Fig. 6). A corresponding decline in the mean number of other prey items consumed (capelin, $F=4.53, \mathrm{p}=0.039$; pollock, $F=$ $13.92, \mathrm{p}<0.001$ ) suggests that predators switched to euphausiids in euphausiidrich areas. This pattern could not be explained by predator size, which was included as a categorical $(10 \mathrm{~mm}$ size bins) effect in the ANCOVA, or by a scarcity of alternate prey in euphausiidrich areas (i.e. the abundance of euphausiid and non-euphausiid plankters were not inversely related: $F=0.33$, $p=0.573, n=18$ ). The importance of euphausiids as the principal prey acquired by these predators is further underscored by the increase in predator stomach fullness with euphausiid plankton abundance (Fig. 6), which indicates that euphausiids comprise the bulk of the diets of these fishes. In fact, euphausiids may be especially important to capelin as evidenced by few mean gut content weights $>0.5 \%$ BW at sites where euphausiid abundance was $<256$ euphausiids $\mathrm{m}^{-2}$. In contrast, the pollock at these sites readily consumed alternate prey.

Prey selectivities differed between capelin and age0 walleye pollock for 4 prey groups. Pairwise differences in prey selectivity were significantly different from 0 for Amphipoda (Wilcoxon, $\mathrm{n}=27, \mathrm{p}<0.001$ ), Copepoda $\geq 2 \mathrm{~mm}$ PL $(\mathrm{n}=34, \mathrm{p}=0.004)$, Larvacea $(\mathrm{n}=$ $24, \mathrm{p}=0.001)$, and Reptantia $(\mathrm{n}=28, \mathrm{p}<0.001)$. Selectivity for each of these groups was relatively high for age- 0 walleye pollock.

\section{DISCUSSION}

Many comparative diet studies have repeatedly demonstrated high potential for competition among forage fishes (Huse \& Toresen 1996, Willette et al. 1997, Sturdevant et al. 2001). Our study indicates that despite much similarity in feeding ecology, differences exist in the way capelin and age- 0 walleye pollock utilize zooplankton. These differences might be interpreted as evidence of competition, but competition is difficult to prove when it is unclear that the resource(s) in common are limiting (Robinson \& Wilson 1994). 


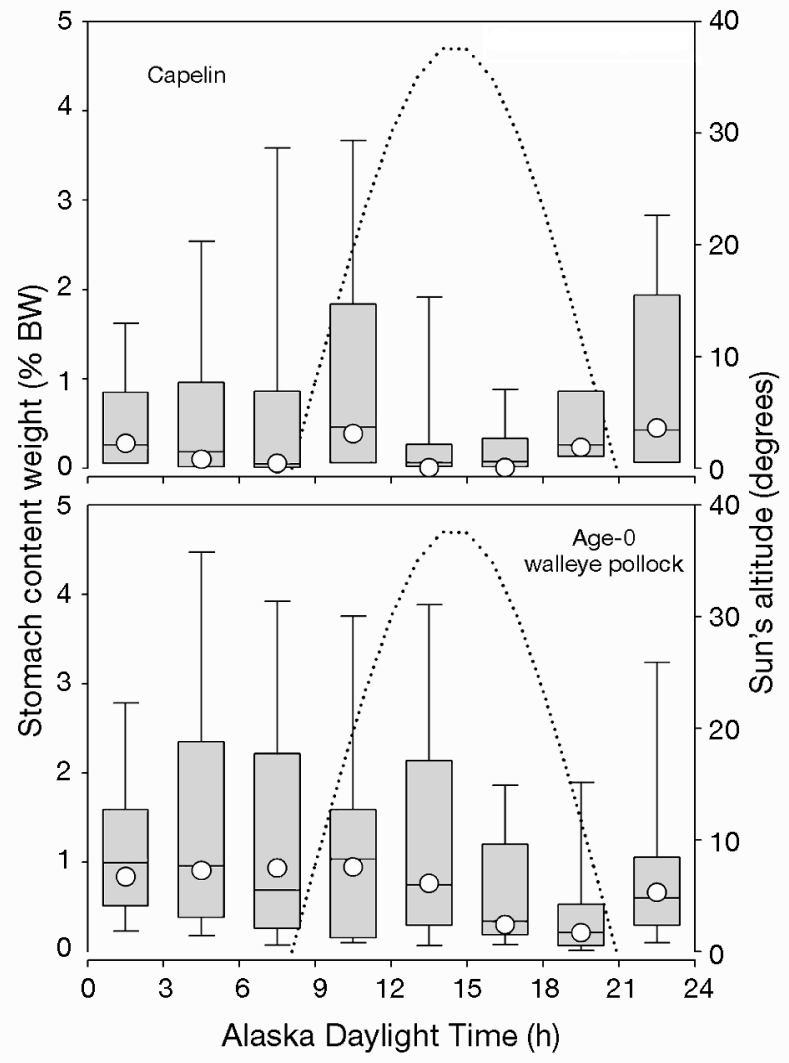

Fig. 5. Mallotus villosus and Theragra chalcogramma. Box plots of stomach content weight (10th, 25th, 50th, 75th, and 90th percentiles), as a percentage of somatic body weight (\% BW), for $3 \mathrm{~h}$ intervals of Alaska Daylight Time (ADT). Dotted line: hourly predictions of sun altitude (see Fig. 3 for coordinates and data source). (O) predicted \% body weight (BW) from the MAXIMS model. See Fig. 3 for number of fish in each time period
Table 5. Mallotus villosus and Theragra chalcogramma. Feeding parameters estimated by fitting MAXIMS models to median stomach fullness ( $\%$ BW) of capelin and age-0 walleye pollock for $3 \mathrm{~h}$ intervals $(\mathrm{n}=8)$. Feeding period start and end times are Alaska Daylight Time

\begin{tabular}{|llrc|}
\hline Species & Parameter & Estimate & SE \\
\hline Capelin & Ingestion (\% BW $\mathrm{h}^{-1}$ ) & 0.1966 & 0.1428 \\
& Evacuation $\left(\mathrm{h}^{-1}\right.$ ) & 0.3524 & 0.3405 \\
& 1st feeding period (start) & 7.4048 & 0.5842 \\
& 1st feeding period (end) & 10.5000 & 2.4042 \\
& 2nd feeding period (start) & 17.9857 & 1.2403 \\
& 2nd feeding period (end) & 23.8750 & 2.0704 \\
& Daily ration (\% BW) & 1.7664 & 1.8639 \\
Age-0 & Ingestion (\% BW $\mathrm{h}^{-1}$ ) & 0.2957 & 0.1210 \\
walleye & Evacuation (h ${ }^{-1}$ ) & 0.3128 & 0.1455 \\
pollock & Feeding period (start) & 19.1714 & 0.5917 \\
& Feeding period (end) & 12.8003 & 0.9782 \\
& Daily ration (\% BW) & 5.2129 & 2.3504 \\
\hline
\end{tabular}

Grover (1990) examined the stomach contents of larval and small age-0 walleye pollock, collected in the GOA during summer, and found high prevalence of small-size copepod genera: Pseudocalanus, Centropages, and Acartia. Similarly, Coyle \& Paul (1992) found these genera in the stomachs of small capelin collected during late spring in southeastern Alaska. Our results indicate that age- 0 walleye pollock and capelin continue to feed on small copepods during autumn. However, it was also obvious that larger prey, primarily euphausiids, become increasingly important as predator size and gape width increases, which is consistent with previous studies (Naumenko 1984,

Table 6. Mallotus villosus and Theragra chalcogramma. Chesson's index of prey selectivity, $\alpha_{i}$, for capelin and age-0 walleye pollock. Preferential selection: $\alpha_{i}>0.063$. Cumacea omitted from Taxonomic group because it was not included in the plankton sample processing protocol. PL: prosome length; $(a+j)$ : adult + juvenile; $(f+c)$ : furcilia + calyptopis

\begin{tabular}{|c|c|c|c|c|c|c|}
\hline \multirow[t]{2}{*}{ Taxonomic group } & \multicolumn{3}{|c|}{ September 2000} & \multicolumn{3}{|c|}{ September 2001} \\
\hline & Pollock & Capelin & $\begin{array}{c}\text { Plankton } \\
\text { No. } / \mathrm{m}^{2}\end{array}$ & Pollock & Capelin & $\begin{array}{r}\text { Plankton } \\
\text { No. } / \mathrm{m}^{2}\end{array}$ \\
\hline Amphipoda & 0.020 & 0.001 & 260 & 0.009 & 0.003 & 1473 \\
\hline Chaetognatha & 0.017 & 0.003 & 420 & 0.012 & 0.004 & 554 \\
\hline Cirripedia & 0.027 & 0.000 & 74 & 0.000 & 0.001 & 1491 \\
\hline Cladocera & 0.000 & 0.000 & 52 & 0.000 & 0.000 & 60282 \\
\hline Radiata (Cnidaria, Ctenophora) & 0.000 & 0.000 & 279 & 0.000 & 0.000 & 361 \\
\hline Copepoda, $<2$ mm PL & 0.016 & 0.008 & 80058 & 0.008 & 0.020 & 62881 \\
\hline Copepoda, $\geq 2 \mathrm{~mm} \mathrm{PL}$ & 0.045 & 0.010 & 1969 & 0.042 & 0.064 & 4315 \\
\hline Euphausiid $(a+j)$ & 0.427 & 0.216 & 135 & 0.208 & 0.619 & 647 \\
\hline Euphausiid $(\mathrm{f}+\mathrm{c})$ & 0.046 & 0.348 & 228 & 0.003 & 0.004 & 1885 \\
\hline Osteichthys & 0.182 & 0.333 & 11 & 0.041 & 0.000 & 28 \\
\hline Larvacea & 0.127 & 0.028 & 254 & 0.579 & 0.220 & 1469 \\
\hline Mysidacea & 0.000 & 0.000 & 7 & 0.037 & 0.000 & 6 \\
\hline Natantia & 0.000 & 0.000 & 41 & 0.000 & 0.000 & 94 \\
\hline Ostracoda & 0.000 & 0.000 & 3 & 0.000 & 0.000 & 19 \\
\hline Reptantia & 0.033 & 0.000 & 403 & 0.008 & 0.000 & 496 \\
\hline Thecosomata & 0.061 & 0.053 & 1590 & 0.053 & 0.065 & 4462 \\
\hline
\end{tabular}



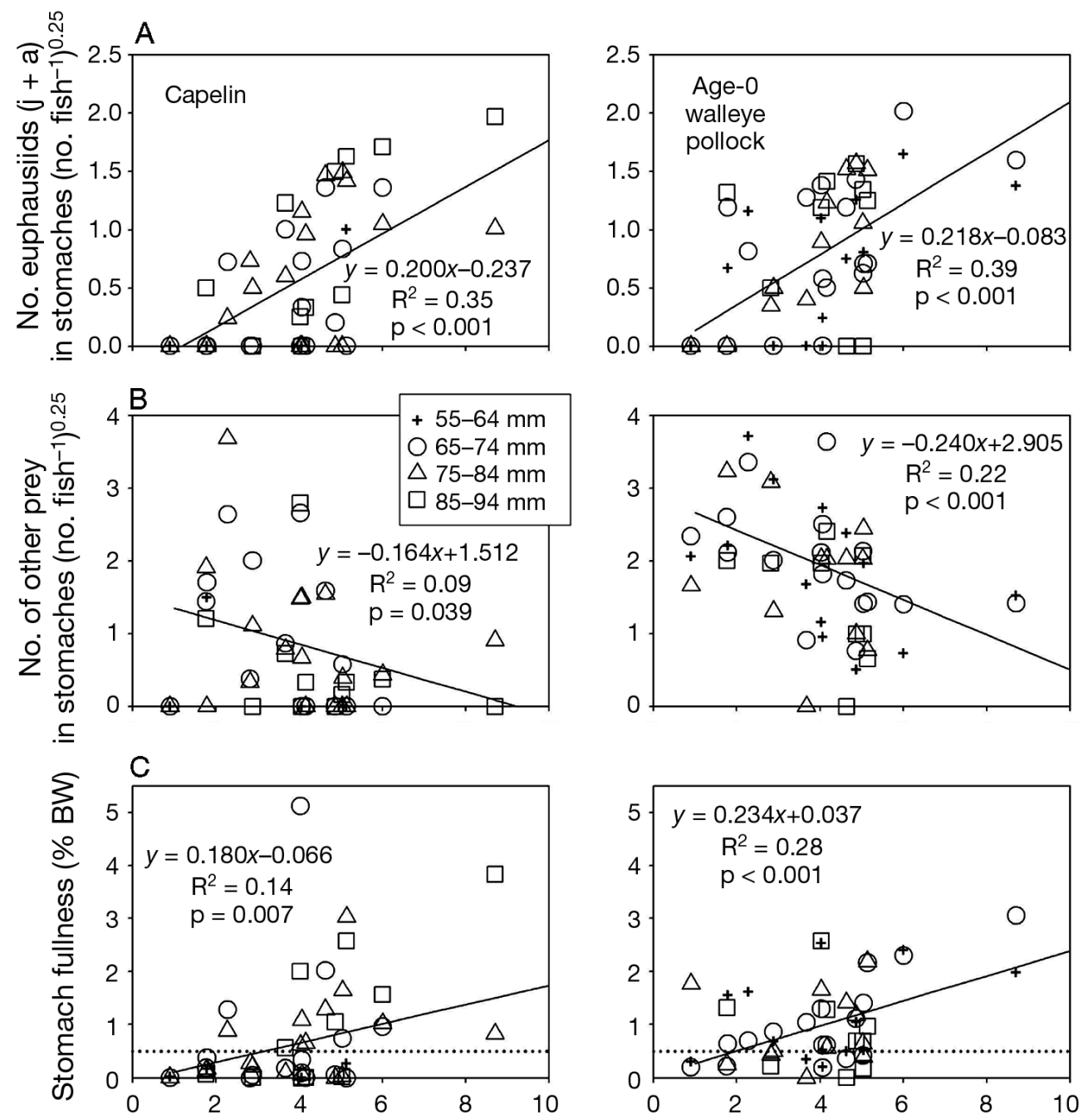

No. euphausiids in plankton (no. $\left.\mathrm{m}^{-2}\right)^{0.25}$

Fig. 6. Mallotus villosus and Theragra chalcogramma. (A) Mean number of juvenile and adult euphausiids, (B) number of alternate prey in capelin and age- 0 walleye pollock stomachs, and (C) median stomach fullness vs the abundance of euphausiids collected from the plankton. Symbols: predator standard-length. Solid lines: least-squares regression from ANCOVA. Dotted horizontal line: reference stomach fullness of $0.5 \%$ BW (see 'Prey selectivity' in 'Results'). Abundances are 4 th-root transformed

(e.g. axis value of 4 back-transforms to 256 )

Schabetsberger et al. 2000). In fact, size-related dietary transitions have been demonstrated for capelin (O'Driscoll et al. 2001) and age-0 pollock (Brodeur 1998). Transition in diet with body size means that the capelin, which were larger on average, should have consumed proportionally few small prey items relative to pollock. However, the prey groups associated with differences in selectivity were not the smallest prey items. In fact, the prey groups differentially consumed suggest that age-0 walleye pollock more readily utilize a broader suite of zooplankton. We recognize that selectivity estimates are vulnerable to difficulties associated with identification of prey in stomach contents and quantitative sampling of potential prey populations (Brodeur 1998), but these are less problematic when a standard method is used to gauge relative differences between predators. Such methodological problems would therefore not likely alter the conclusion that age-0 walleye pollock more fully utilize the range of available prey resources. Indeed, in our study area, the geographic distribution of age-0 walleye pollock encompassed that of capelin indicating a more extensive occupation of the coastal environment (M. Wilson unpubl. data); however, it is not yet evident that capelin were more geographically constrained by prey availability than were age-0 pollock.

Daily ration estimates for capelin $(1.8 \% \mathrm{BW})$ and age-0 walleye pollock $(5.2 \% \mathrm{BW})$ in the GOA during September 2000 to 2001 were within the range of most other field-based estimates. Capelin daily ration was 
previously estimated to be 1.3 to $2.2 \%$ BW (Barents Sea, Ajiad \& Pushchaeva 1992), 1.8\% BW (Bering Sea, Naumenko 1987), and 2.5 to $5 \%$ BW (Gulf of St. Lawrence, Vesin et al. 1981). Ajiad \& Puschaeva (1992) report a gastric evacuation rate of $0.1037 \%$ BW $\mathrm{h}^{-1}$, which is lower than our estimate possibly due to colder Arctic water and somewhat larger fish (6 to $18 \mathrm{~cm}$ ). For age-0 walleye pollock, our estimate of gastric evacuation rate was similar to the estimates (0.25 to $0.28 \% \mathrm{BW} \mathrm{h}^{-1}$ ) of Merati \& Brodeur (1996). Daily ration for age-0 walleye pollock was previously estimated to be 1.0 to $2.5 \%$ BW (eastern Bering Sea, Brodeur et al. 2000) and 7.4 to $8.5 \%$ BW (western GOA, Merati \& Brodeur 1996); this latter estimate may be relatively high due to the inclusion of samples collected near Kodiak Island where euphausiids were an especially prominent dietary component. Ciannelli et al. (2004) estimated a very high daily ration (16 to $21 \% \mathrm{BW}$ ) relative to both our estimate and to the ad libitum (10\% BW) ration of laboratory-held fish (Sogard \& Olla 1996). This discrepancy might be due to the relatively small size of fish examined by Ciannelli et al. (2004), and to errors associated with model-based estimates (Bajer et al. 2004).

Feeding parameter estimates depend heavily on observed diel patterns in stomach fullness. This can be problematic because stomach fullness data are characterized as highly variable (Richter et al. 1999). Our observation of crepuscular feeding by capelin, however, agrees with that observed by Vesin et al. (1981) studying capelin in the northwest Atlantic. Vesin et al. (1981) associated crepuscular feeding with transitional periods in the diel vertical migration of prey and predator, possibly in response to predator-prey perception dynamics (Johnsen 2005). For small fishes foraging in exposed areas, crepuscular feeding optimizes the trade-off between food intake and predation risk (Clark \& Levy 1988). Vesin et al. (1981) noted that during winter, capelin shift to diurnal feeding possibly in response to photoperiod compression. In contrast, age0 pollock $\geq 50 \mathrm{~mm}$ tend to feed nocturnally (Brodeur et al. 2000), and have been shown to be effective foragers in low-light conditions (Ryer \& Olla 1999). The decrease in stomach fullness during the day, when capelin (Mowbray 2002) and age-0 walleye pollock (Brodeur and Wilson 1996) are at depth, suggests that prey availability or some other factor, e.g. predation risk (Lang et al. 2000, Mowbray 2002), inhibits feeding.

Our observation of low daily ration for capelin as compared to age-0 walleye pollock was not explained by any indication of poor body condition. The capelin length-weight relationship was similar to those of capelin in the Barents Sea during autumn (Gjøsæter 1998) and, after conversion to FL (Buchheister \& Wilson 2005), similar to capelin in Prince William Sound
(Brown 2002). However, autumn appears to be a time of reduced feeding by capelin as noted by Vesin et al. (1981). Furthermore, the low daily ration of capelin might also reflect their nearly mature size $(10$ to $13 \mathrm{~cm}$ FL, Pahlke 1985) and reduced somatic growth $(0.3 \mathrm{~mm}$ $\mathrm{d}^{-1}$, Brown 2002, Gjøsæeter 1998). In contrast, age-0 walleye pollock grow at approximately $0.9 \mathrm{~mm} \mathrm{~d}^{-1}$ (Bailey et al. 1996a) undergoing a 4 -fold increase in length before spawning as age-4 individuals. Thus, differences in stomach fullness likely reflect different ontogenetic states and consequent nutritional demands and physiological priorities with regard to energy storage versus utilization for growth. Alternatively, because capelin and age-0 walleye pollock share major prey groups, the observed differences in diet and feeding intensity could reflect the adverse effects of competition; however, again, it is not clear that prey resources were limiting.

Gjøsæter et al. (2002) and Yamamura et al. (2002) studied capelin and walleye pollock respectively and suggested that these fishes can significantly impact the standing stocks of large zooplankton, possibly to the point of becoming prey limited. The positive association we observed between euphausiids in predator stomachs and in the plankton indicates that the variation in euphausiid availability was sufficient to affect predator diet. This response was somewhat speciesspecific in that age- 0 walleye pollock were inclined to consume other prey while capelin reduced consumption at euphausiid-poor locations. The apparent avoidance by capelin to utilize alternate prey may indicate a relatively specialized diet and could relate to their relatively high body energy density. The body lipid content of Thysanoessa inermis increases in autumn (FalkPetersen et al. 2000) such that they become one of the more energy-rich prey groups available to these predators (M. Wilson unpubl. data). On average, daily consumption of euphausiids by the capelin and age-0 walleye pollock populations in the study area was only $2.4 \%( \pm 1.6 \mathrm{SE}, \mathrm{n}=18)$ of the standing stock, which agrees with Ciannelli et al. (1998) that in the western GOA there is little evidence of widespread limitation of prey. These estimates, however, may not be generally applicable due to fluctuations in predator (Bailey et al. 1996b, Dorn et al. 2004) and prey (Sugimoto \& Tadokoro 1997) populations, and because they do not account for consumption by other zooplanktivores, or spatial patchiness in predator and prey populations (De Robertis 2002). With regard to localized depletion, based on our daily ration and diet proportion estimates for capelin and age-0 walleye pollock, it seems likely that the standing stock of euphausiid abundance was depleted in at least some locations within our study area. Using only samples collected at night, the maximum site-specific daily consumption by fish was $30 \%$ 
of the euphausiid standing stock suggesting that local depletion of euphausiids could occur. Thus, it seems likely that localized depletion of euphausiids could be a governing force in the adaptation of foraging strategy by capelin and age- 0 walleye pollock.

If localized depletion of euphausiids commonly occurs in the presence of capelin and age- 0 walleye pollock, then these fishes can be expected to compete. Capelin may be relatively specialised at foraging on euphausiid patches based on their tendency to reduce feeding when these prey were in low abundance. We therefore suggest that capelin may be superior to age0 walleye pollock at locating and cropping euphausiid patches. In contrast, age-0 walleye pollock readily consume alternate prey types indicating that they may be superior to capelin at grazing on a variety of ambient zooplankton. As such, capelin may have feeding advantages over pollock during periods when euphausiids are present but underexploited. Conversely, pollock feeding may be favoured during periods when euphausiids are limiting or absent since pollock demonstrate a tendency toward greater diet diversity and foraging flexibility. These traits could contribute to the success of one species over the other in differing regimes.

Acknowledgements. K. Bailey provided the original impetus for this work. We are grateful to the captain and crew of the NOAA Ship 'Miller Freeman', and the many scientists who assisted with sample collection. A. Dougherty was particularly helpful dissecting fish. J. Napp helped with copepod identification. K. Mier provided much statistical help and discussion. We also thank K. Bailey, T. Buckley, P. Livingston, M. Mazur, K. Mier, J. Napp, M.S. Yang, the AFSC Publications Unit, and 3 anonymous reviewers for comments on the manuscript. M. Mazur generously discussed ideas on fish foraging, and H. Gjøsæter kindly provided literature on capelin in the northern Atlantic. This research is contribution FOCI0418 to NOAA's Fisheries-Oceanography Coordinated Investigations. Supported by grants to M.T.W. and J.T.D.-A. from the Sea Lion Research Inititiative (Grant No. 02FF-04), and the North Pacific Research Board (Grant No. R0308). Reference in the present study to trade names does not imply endorsement by the National Marine Fisheries Service, NOAA.

\section{LITERATURE CITED}

Abookire AA, Piatt JF (2005) Oceanographic conditions structure forage fishes into lipid-rich and lipid-poor communities in lower Cook Inlet, Alaska, USA. Mar Ecol Prog Ser 287:229-240

Ajiad AM, Pushchaeva TY (1992) The daily feeding dynamics in varous length groups of the Barents Sea capelin. In: Bogstad B, Tjelmeland S (eds) Interrelations between fish populations in the Barents Sea. Proc 5th PINRO-IMR Symp, Murmansk, Institute of Marine Research, Bergen, p 181-192

Anderson PJ, Piatt JF (1999) Community reorganization in the Gulf of Alaska following ocean climate regime shift. Mar
Ecol Prog Ser 189:117-123

Anthony JA, Roby DD, Torco KR (2000) Lipid content and energy density of forage fishes from the northern Gulf of Alaska. J Exp Mar Biol Ecol 248:53-78

Bailey KM, Brown AL, Yoklavich MM, Mier KL (1996a) Interannual variability in growth of larval and juvenile walleye pollock, Theragra chalcogramma, in the western Gulf of Alaska, 1983-91. Fish Oceanogr 5(Suppl 1):137-147

Bailey KM, Brodeur RD, Hollowed AB (1996b) Cohort survival patterns of walleye pollock, Theragra chalcogramma, in Shelikof Strait, Alaska: a critical factor analysis. Fish Oceanogr 5(Suppl 1):179-188

Bajer PG, Hayward RS, Whitledge GW, Zweifel RD (2004) Simultaneous identification and correction of systematic error in bioenergetics models: demonstration with a white crappie (Pomoxis annularis) model. Can J Fish Aquat Sci 61:2168-2182

Brodeur RD (1998) Prey selection by age-0 walleye pollock, Theragra chalcograma, in nearshore waters of the Gulf of Alaska. Environ Biol Fishes 51:175-186

Brodeur RD, Wilson MT (1996) A review of the distribution, ecology, and population dynamics of age- 0 walleye pollock in the Gulf of Alaska. Fish Oceanogr 5(Suppl 1):148-166

Brodeur RD, Wilson MT, Ciannelli L (2000) Spatial and temporal variability in feeding and condition of age- 0 walleye pollock (Theragra chalcogramma) in frontal regions of the Bering Sea. ICES J Mar Sci 57:256-264

Brown ED (2002) Life history, distribution, and size structure of Pacific capelin in Prince William Sound and the northern Gulf of Alaska. ICES J Mar Sci 59:983-996

Buchheister A, Wilson MT (2005) Shrinkage correction and length conversion equations for walleye pollock (Theragra chalcogramma), capelin (Mallotus villosus), and eulachon (Thaleichthys pacificus). J Fish Biol 67:541-548

Cailliet GM, Barry JP (1979) Comparison of food array overlap measures useful in fish feeding habit analysis. In: Lipovsky SJ, Simenstad CA (eds) Gutshop '78, Fish food habits studies: proceedings of the 2nd Pacific Northwest technical workshop. Washington Sea Grant Report WSGWO-79-1. University of Washington Division of Marine Resources, Seattle, p 67-79

Chesson J (1978) Measuring preference in selective predation. Ecology 59(2):211-215

Clark CW, Levy DA (1988) Diel vertical migrations by juvenile sockeye salmon and the antipredation window. Am Nat 131(2):271-290

Ciannelli L, Brodeur RD, Buckley TW (1998) Development and application of a bioenergetics model for juvenile walleye pollock. J Fish Biol 52:879-898

Ciannelli L, Brodeur RD, Napp JM (2004) Foraging impact on zooplankton by age-0 walleye pollock (Theragra chalcogramma) around a front in the southeast Bering Sea. Mar Biol 144:515-526

Coyle KO, Paul AJ (1992) Interannual differences in prey taken by capelin, herring, and red salmon relative to zooplankton abundance during the spring bloom in a southeast Alaskan embayment. Fish Oceanogr 1(4):294-305

Coyle KO, Pinchuk AL (2003) Annual cycle of zooplankton abundance, biomass, and production on the northern Gulf of Alaska shelf, October 1997 through October 2000. Fish Oceanogr 12:327-338

Cury P, Bakun B, Crawford RJM, Jarre A, Quiñones A, Shannon LJ, Verheye HM (2000) Small pelagics in upwelling systems: patterns of interaction and structural changes in 'wasp-waist' ecosystems. ICES J Mar Sci 57:603-618

De Robertis A (2002) Small-scale spatial distribution of the euphausiid Euphausia pacifica and overlap with planktiv- 
orous fishes. J Plankton Res 24(11):1207-1220

Dorn M, Barbeaux S, Gaichas S, Guttormsen M, Megrey B, Spalinger K, Wilkins M (2004) Assessment of walleye pollock in the Gulf of Alaska. In: Stock assessment fishery evaluation report. Groundfish Resources of the Gulf of Alaska, Anchorage, AK, p 35-129 (available at www.afsc. noaa.gov/refm/docs/2004/GOApollock.pdf)

Duffy-Anderson JT, Bailey KM, Ciannelli L (2002) Consequences of a superabundance of larval walleye pollock Theragra chalcogramma in the Gulf of Alaska in 1981. Mar Ecol Prog Ser 243:179-190

Eder EB, Lewis MN (2005) Proximate composition and energetic value of demersal and pelagic prey species from the SW Atlantic Ocean. Mar Ecol Prog Ser 291:43-52

Falk-Petersen S, Hagen W, Kattner G, Clarke A, Sargent J (2000) Lipids, trophic relationships, and biodiversity in Arctic and Antarctic krill. Can J Fish Aquat Sci 57(Suppl 3):178-191

Folt CL, Burns CW (1999) Biological drivers of zooplankton patchiness. Trends Ecol Evol 14(8):300-305

Gjøsæter H (1998) The population biology and exploitation of capelin (Mallotus villosus) in the Barents Sea. Sarsia 83: 453-496

Gjøsæter H, Dalpadado P, Hassel A (2002) Growth of Barents Sea capelin (Mallotus villosus) in relation to zooplankton abundance. ICES J Mar Sci 59:959-967

Grover JJ (1990) Feeding ecology of late-larval and earlyjuvenile walleye pollock Theragra chalcogramma from the Gulf of Alaska in 1987. Fish Bull 88:463-470

Hatch SA, Sanger GA (1992) Puffins as samplers of juvenile pollock and other forage fish in the Gulf of Alaska. Mar Ecol Prog Ser 80:1-14

Horn HS (1966) Measurement of 'overlap' in comparative ecological studies. Am Nat 100:419-424

Hunt GL, Stabeno P, Walters G, Sinclair E, Brodeur RD, Napp JM, Bond NA (2002) Climate change and control of the southeastern Bering Sea pelagic ecosystem. Deep-Sea Res II 49:5821-5853

Huse G, Toresen R (1996) A comparative study of the feeding habits of herring (Clupea harengus, Clupeidae, L.) and capelin (Mallotus villosus, Osmeridae, Müller) in the Barents Sea. Sarsia 81:143-153

Iverson SJ, Frost KT, Lang SLC (2002) Fat content and fatty acid composition of forage fish and invertebrates in Prince William Sound, Alaska: factors contributing to among and within species variability. Mar Ecol Prog Ser 241:161-181

Johnsen S (2005) Visual ecology on the high seas. In: Weissburg MJ, Browman HI (eds) Sensory biology: linking the internal and external ecologies of marine organisms. Mar Ecol Prog Ser 287:281-285

Kathman RD, Austin WC, Saltman JC, Fulton JD (1986) Identification manual to the Mysidacea and Euphausiacea of the northeast Pacific. Can Spec Publ Fish Aquat Sci 93

Lang GM, Brodeur RD, Napp JM, Schabetsberger R (2000) Variation in groundfish predation on juvenile walleye pollock relative to hydrographic structure near the Pribilof Islands, Alaska. ICES J Mar Sci 57:265-271

Lechowicz MJ (1982) The sampling characteristics of electivity indices. Oecologia 52:22-30

Mecklenburg CW, Mecklenburg TA, Thorsteinson LK (2002) Fishes of Alaska. American Fisheries Society, Bethesda, MD

Merati N, Brodeur RD (1996) Feeding habits and daily ration of juvenile walleye pollock in the western Gulf of Alaska. NOAA Tech Rep NMFS 126:69-83

Mowbray FK (2002) Changes in the vertical distribution of capelin (Mallotus villosus) off Newfoundland. ICES J Mar
Sci 59:942-949

Naumenko EA (1984) Diet of Pacific capelin, Mallotus villosus socialis (Osmeridae), in the Bering Sea. J Ichthyol 24(3): 130-134

Naumenko EA (1987) Daily feeding rhythm and ration of the capelin, Mallotus villosus socialis (Osmeridae), in the southeastern part of the Bering Sea during winter. J Ichthyol 27(1):158-161

O'Driscoll RL, Parsons MJD, Rose GA (2001) Feeding of capelin (Mallotus villosus) in Newfoundland waters. Sarsia 86:165-176

Orlova EL, Ushakov NG, Nesterova VN, Boitsov VD (2002) Food supply and feeding of capelin (Mallotus villosus) of different size in the central latitudinal zone of the Barents Sea during intermediate and warm years. ICES J Mar Sci 59:968-975

Pahlke KA (1985) Life history and distribution of capelin, Mallotus villosus, in Alaskan waters. MS thesis, University of Alaska, Juneau, AK

Payne SA, Johnson BA, Otto RS (1999) Proximate composition of some north-eastern Pacific forage fish species. Fish Oceanogr 8(3):159-177

Robinson BW, Wilson DS (1994) Character release and displacement in fishes: a neglected literature. Am Nat 144(4): 596-627

Richter H, Focken U, Becker K (1999) A review of the fish feeding model MAXIMS. Ecol Model 120:47-64

Ryer CH, Olla BL (1999) Light-induced changes in the prey consumption and behavior of 2 juvenile planktivorous fish. Mar Ecol Prog Ser 181:41-51

Sainsbury KJ (1986) Estimation of food consumption from field observations of fish feeding cycles. J Fish Biol 29:23-36

Schabetsberger R, Brodeur RD, Ciannelli L, Napp JM, Swartzman GL (2000) Diel vertical migration and interaction of zooplankton and juvenile walleye pollock (Theragra chalcogramma) at a frontal region near the Pribilof Islands, Bering Sea. ICES J Mar Sci 57(4):1283-1295

Smith EP, Zaret TM (1982) Bias in estimating niche overlap. Ecology 63(5):1248-1253

Springer AM, Speckman SG (1997) A forage fish is what? Summary of the Symposium. In: Forage fishes in marine ecosystems. Proc Int Symp Role of Forage Fishes in Marine Ecosystems. Report No. 97-01. University of Alaska Sea Grant College Program, p 773-805

Sogard SM, Olla BL (1996) Food deprivation affects vertical distribution and activity of a marine fish in a thermal gradient: potential energy-conserving mechanisms. Mar Ecol Prog Ser 133:43-55

Sturdevant MV (1999) Forage fish diet overlap, 1994-1996. Exxon Valdez Oil Spill Restoration Project Final Rep No. 98163C, NOAA NMFS, Juneau, AK

Sturdevant MV, Brase ALJ, Hulbert LB (2001) Feeding habits, prey fields, and potential competition of young-of-theyear walleye pollock (Theragra chalcogramma) and Pacific herring (Clupea pallasi) in Prince William Sound, Alaska, 1994-1995. Fish Bull 99:482-501

Sugimoto T, Tadokoro K (1997) Interannual-interdecadal variations in zooplankton biomass, chlorophyll concentration and physical environment in the subarctic Pacific and Bering Sea. Fish Oceanogr 6(2):74-93

Szabo I, Gardner GA (1982) British Columbia pelagic marine copepoda: an identification manual and annotated bibliography. Can Spec Publ Fish Aquat Sci 62

Vesin J-P, Leggett WC, Able KW (1981) Feeding ecology of capelin (Mallotus villosus) in the estuary and western Gulf of St. Lawrence and its multispecies implications. Can J Fish Aquat Sci 38(3):257-267 
Willette M, Sturdevant M, Jewett S (1997) Prey resource partitioning among several species of forage fishes in Prince William Sound, Alaska. In: Forage fishes in marine ecosystems. Proc Int Symp Role of Forage Fishes in Marine Ecosystems. Report No. 97-01. University of Alaska Sea Grant College Program, p 11-29

Wilson MT (2000) Effects of year and region on the abundance and size of age-0 walleye pollock, Theragra chalcogramma, in the western Gulf of Alaska, 1985-1988. Fish Bull 98:823-834

Wilson MT, Brodeur RD, Hinckley S (1996) Distribution and abundance of age-0 walleye pollock, Theragra chalcogramma, in the western Gulf of Alaska during September 1990. NOAA Tech Rep NMFS 126:11-24

Wilson MT, Dougherty AL, Mier KL (2005) Variation among age-0 walleye pollock (Theragra chalcogramma): evi-

Editorial responsibility: Kenneth Sherman (Contributing Editor), Narragansett, Rhode Island, USA dence of meso-scale geographic variation in nursery quality? Fish Bull 103(1):207-218

Yamamura O, Honda S, Shida O, Hamatsu T (2002) Diets of walleye pollock Theragra chalcogramma in the Doto area, northern Japan: ontogenetic and seasonal variations. Mar Ecol Prog Ser 238:187-198

Yang MS, Nelson MW (2000) Food habits of the commercially important groundfishes in the Gulf of Alaska in 1990, 1993, and 1996. NOAA Tech Memo NMFS 112:1-174

Yang MS, Aydin K, Grieg A, Lang G, Livingston P (2005) Historical review of capelin (Mallotus villosus) consumption in the Gulf of Alaska and eastern Bering Sea. NOAA Tech Memo NMFS155:1-89

Zeppelin TK, Sinclair EH (2002) Seasonal and spatial differences in diet in the western stock of Steller sea lions (Eumetopias jubatus) J Mammal 83(4):973-990

Submitted: June 29, 2005; Accepted: December 27, 2005

Proofs received from author(s): June 8, 2006 